\title{
Struktur Komunitas Plankton Pada Muara Sungai Enam, Kabupaten Bintan, Provinsi Kepulauan Riau
}

\author{
The Structure of Plankton Community in Estuary of Sungai Enam, Bintan Regency, \\ Riau Island Province
}

\author{
Lani Puspita $^{1 *}$ \\ ${ }^{1}$ Program Studi Pendidikan Biologi, FKIP, Universitas Riau Kepulauan, Batam \\ *Koresponden: lanipuspita@ fkip.unrika.ac.id
}

\begin{abstract}
Abstrak
Kelurahan Sei Enam, Kecamatan Bintan Timur merupakan salah satu daerah pertambangan bauksit di Kabupaten Bintan. Salah satu dampak dari kegiatan pertambangan bauksit adalah penurunan kualitas air di badan air penerima karena adanya limbah tailing (khususnya apabila tailing tidak dikelola dengan baik). Penelitian ini bertujuan untuk mengetahui struktur komunitas fitoplankton dan zooplankton di Muara Sungai Enam, yang meliputi jumlah taxa, komposisi jenis, keanekaragaman jenis, keseragaman jenis, dan dominansi jenis. Hasil penelitian ini diharapkan dapat dijadikan informasi bermanfaat untuk mengambarkan kondisi lingkungan perairan di Muara Sungai Enam Kabupaten Bintan. Berdasarkan hasil penelitian, dapat disimpulkan bahwa keanekaragaman jenis plankton di Muara Sungai Enam tergolong rendah. Hal ini karena muara sungai merupakan daerah peralihan (ekoton) antara ekosistem darat dengan ekosistem laut. Salinitas di perairan ekosistem ekoton ini diprediksi sangat bervariasi, kondisi ini membuat hanya spesies-spesies dengan daya toleransi cukup tinggi saja yang dapat hidup daerah ini. Walaupun demikian produktivitasnya cukup baik karena fitoplankton yang mendominasi adalah Nannochloropsis oculata. Nannochloropsis oculata pada perairan berperan sebagai pakan alami larva-larva ikan. Sejalan dengan fitoplankton, zooplankton yang merupakan herbivora primer juga memiliki keanekaragaman jenis yang rendah.
\end{abstract}

Kata kunci: Struktur Komunitas, Plankton, Kabupaten Bintan

\begin{abstract}
Abstact
Sei Enam Village, East Bintan District is one of the bauxite mining areas in Bintan Regency. One of the impacts of bauxite mining activities is the deterioration of water quality in the recipient water bodies due to tailings (especially if tailings are not properly managed). This study aims to determine the structure of phytoplankton and zooplankton communities in Estuary of Sungai Enam, which include taxa number, species composition, species diversity, species uniformity, and species dominance. The results of this study are expected to be useful information to describe the environmental conditions of waters in the Estuary of the Sungai Enam Bintan Regency. Based on the research results, it can be concluded that the diversity of plankton species in the estuary of the River Enam is low. This is because the river mouth is an intermediate (ecotonic) area between the terrestrial ecosystem and the marine ecosystem. Salinity in the waters of this ecotonic ecosystem is predicted to vary greatly, making it possible for only species with a high tolerance tolerance to live in this area. However, the productivity is quite good because the dominant phytoplankton is Nannochloropsis oculata. Nannochloropsis oculata in waters acts as a natural food of fish larvae. In line with phytoplankton, zooplankton which is a primary herbivore also has a low species diversity.
\end{abstract}

Keywords: Community Structure, Plankton, Bintan Regency 


\section{PENDAHULUAN}

Kelurahan Sei Enam, Kecamatan Bintan Timur merupakan salah satu daerah pertambangan bauksit di Kabupaten Bintan. Pada daerah ini ada beberapa perusahaan pertambangan bijih bauksit yang beroperasi. Keseluruhan luas areal yang diperuntukkan dan dibuka untuk pertambangan bijih bauksit di Kecamatan Bintan Timur mencapai lebih dari $2.500 \mathrm{Ha}$.

Salah satu kegiatan pada pertambangan bijih bauksit adalah pencucian bijih bauksit dari kotoran tanah dan clay, jumlah pengotor bijih bauksit ini dapat mencapai $50-60 \%$ dari total bauksit yang ditambang. Pengotor bijih bauksit hasil pencucian ini dikenal dengan istilah tailing. Kegiatan pencucian bijih bauksit biasanya dilakukan di dekat sumber air (sungai atau laut), dan tailing yang dihasilkan dibuang ke kolam sedimentasi tailing. Di Kelurahan Sei Enam, perusahaan pertambangan umumnya tidak membangun kolam sedimentasi tailing pada lokasi yang tepat dengan kapasitas yang memadai, sehingga tailing melimpas (running off) ke perairan di sekitarnya. Limpasan tailing ke perairan ini akan berpengaruh pada struktur komunitas biota yang hidup di perairan tersebut, diantaranya fitoplankton dan zooplankton.

Plankton adalah organisme akuatik yang tidak memiliki kemampuan untuk bergerak melawan arus, sehingga persebarannya sangat dipengaruhi oleh arus air. Umumnya plankton berukuran renik, walaupun ada juga plankton berukuran besar yang disebut sebagai megaplankton (salah satu contohnya adalah Ubur-Ubur Scyphomedusa). Berdasarkan cara memperoleh nutrisinya, plankton bisa dibedakan menjadi Fitoplankton dan Zooplankton. Fitoplankton adalah kelompok plankton yang bisa berfotosintesis atau bersifat autotrof; sedagkan zooplankton adalah kelompok plankton yang bersifat heterotrof (Nontji, 2008).

Dalam ekosistem perairan, fitoplankton berperan seperti tumbuhan yang menentukan produktivitas perairan. Fitoplankton dan zooplankton sering juga dipakai sebagai indikator biologis terhadap adanya perubahan kondisi lingkungan perairan, misalnya masuknya bahanbahan pencemar ke dalam perairan yang dapat menimbulkan dampak negatif bagi keseimbangan ekosistem (Fachrul, 2012).

Pada studi ini dilakukan pengamatan komposisi fitoplankton dan zooplankton di Muara Sungai Enam. Di sekitar lokasi pengambilan sampel plankton terdapat instalasi pencucian bauksit salah satu perusahaan tambang, jalan tambang, dan hutan mangrove. Hasil studi ini diharapkan dapat memberikan gambaran struktur komunitas plankton di Muara Sungai Enam yang berada di wilayah pertambangan bijih bauksit. 
Penelitian ini bertujuan untuk mengetahui struktur komunitas fitoplankton dan zooplankton di Muara Sungai Enam, yang meliputi jumlah taxa, komposisi jenis, keanekaragaman jenis, keseragaman jenis, dan dominansi jenis. Hasil penelitian ini diharapkan dapat dijadikan informasi bermanfaat untuk mengambarkan kondisi lingkungan perairan di Muara Sungai Enam Kabupaten Bintan.

\section{METODE PENELITIAN}

Pengambilan sampel plankton dilakukan di Muara Sungai Enam, Kelurahan Sei Enam, Kabupaten Bintan. Pengambilan sampel dilakukan pada tanggal 7 Juni 2008, pukul 17.05 WIB. Kondisi cuaca pada saat pengambilan sampel adalah mendung dan gerimis, dengan kecerahan perairan $\pm 20 \mathrm{~cm}$. Identifikasi jenis fitoplankton dan zooplankton dilakukan di Laboratorium Pakan Alami, Balai Budidaya Laut Batam, pada tanggal 10 Juni 2008.

Peralatan yang digunakan pada studi ini meliputi: plankton-net dengan mesh size 10 $\mu \mathrm{m}$, botol sampel plankton bervolume $10 \mathrm{ml}$, gelas ukur bervolume 11 , mikroskop, gelas preparat, pipet tetes, cool box, lemari pendingin, tissue, buku identifikasi, dan handy-counter. Sedangkan bahan yang digunakan pada studi ini adalah es, lugol 10\%, dan aquades.

Pengambilan sampel plankton dilakukan dengan menyaring 10 liter air sungai menggunakan plankton-net. Agar volume air sungai yang disaring tepat 10 liter, digunakan gelas ukur bervolume 1 liter. Pengambilan sampel dilakukan secara komposit horizontal di permukaan perairan. Sampel plankton yang terkumpul pada botol sampel kemudian diawetkan dengan disimpan pada cool box. Sampel plankton yang telah diawetkan kemudian dibawa ke laboratorium untuk diidentifikasi dan dihitung kelimpahannya.

Analisa sampel fito dan zooplankton di laboratorium dilakukan dengan pengamatan di bawah mikroskop untuk mengidentifikasi jenis fito dan zooplankton serta mengetahui jumlah individu masing-masing jenis fito dan zooplankton. Dengan mengetahui jenis dan jumlah individu masing-masing jenis, kita kemudian dapat menghitung kelimpahan fito dan zooplankton, komposisi jenis, keanekaragaman jenis, keseragamanan jenis, dan dominansi jenis. Pengamatan fito dan zooplankton dengan mikroskop dilakukan dengan tahapan berikut: (1) mengocok air sampel plankton dalam botol sampel agar homogen, dan (2) mengambil air sampel dari botol sampel dengan pipet tetes untuk kemudian diteteskan pada preparate glass. 
Pengamatan fito dan zooplankton pada preparate glass dilakukan dengan metode sapuan. Perhitungan kelimpahan jenis fito dan zooplankton dengan metode sapuan adalah sebagai berikut:

$$
N_{i}=\frac{n_{i}}{V_{o}} \times \frac{V_{r}}{V_{s}}
$$

Keterangan:

$\mathrm{N}_{\mathrm{i}}=$ kelimpahan fito atau zooplankton jenis ke-i (individu/liter).

$\mathrm{n}_{\mathrm{i}}=$ jumlah total individu fito atau zooplankton jenis ke-i dari seluruh bidang pandang

$\mathrm{Vr}=$ volume air contoh hasil saringan dalam botol sampel (ml), yaitu $10 \mathrm{ml}$.

$V_{0}=$ volume satu tetes air contoh $(\mathrm{ml})$, yaitu $0,05 \mathrm{ml}$.

$\mathrm{Vs}$ = volume air yang disaring oleh plankton-net (Iiter), yaitu 10 liter.

Setelah didapatkan kelimpahan masing-masing jenis plankton, dilakukan analisa terhadap struktur komunitasnya, yang meliputi: keanekaragaman jenis , keseragaman jenis, dan dominansi jenis (Odum, 1997).

\section{Keanekaragaman Jenis}

Keanekaragaman jenis dihitung dengan menghitung Indeks Keanekaragaman Jenis ShannonWienner (H'). Rumusnya adalah sebagai berikut:

$$
H^{\prime}=\sum\left(\frac{n_{i}}{N} \bullet \ln \frac{n_{i}}{N}\right)
$$

Kisaran nilai:

$0 \leq \mathrm{H}^{\prime}<1 \quad$ tingkat keanekaragaman jenis rendah

$1 \leq \mathrm{H}^{\prime}<3 \quad$ tingkat keanekaragaman jenis sedang

$\mathrm{H}^{\prime} \geq 3 \quad$ tingkat keanekaragaman jenis tinggi

\section{Keseragaman Jenis}

Keseragaman jenis dihitung dengan menghitung Indeks Keseragaman Jenis Evenness (E).

Rumusnya adalah sebagai berikut:

$$
E=\frac{H^{\prime}}{\ln S}
$$

Keterangan:

$\mathrm{E}=$ indeks keseragaman Evenness

$\mathrm{H}^{\prime}=$ indeks keanekaragaman Shannon - Wienner

$\ln =$ logaritma natural

$\mathrm{S} \quad=$ jumlah species plankton 
Kisaran nilai:

$0 \leq \mathrm{E}<0,3$

tingkat keseragaman jenis rendah

$0,3 \leq \mathrm{E}<0,6$

tingkat keseragaman jenis sedang

$\mathrm{E} \geq 0,6$

tingkat keseragaman jenis tinggi

\section{Dominansi Jenis}

Dominansi jenis dihitung dengan menghitung Indeks Dominansi Simpson. Rumusnya adalah sebagai berikut:

$$
D=\sum\left(\frac{n_{i}}{N}\right)^{2}
$$

Keterangan:

$\mathrm{D}=$ indeks dominansi simpson

$\mathrm{n}_{\mathrm{i}}=$ kelimpahan plankton jenis ke-i

$\mathrm{N}=$ kelimpahan total keseluruhan jenis plankton

Kisaran nilai:

$0 \leq \mathrm{D}<0,3 \quad$ tingkat dominansi jenis rendah

$0,3 \leq \mathrm{D}<0,6 \quad$ tingkat dominansi jenis sedang

$\mathrm{D} \geq 0,6 \quad$ tingkat dominansi jenis tinggi

\section{HASIL DAN PEMBAHASAN}

Hasil penelitian ini menunjukkan keanekaragaman fitoplankton di wilayah studi tergolong rendah (kurang dari 1). Hal ini dapat dipahami karena muara sungai bersebelahan dengan ekosistem mangrove. Ekosistem mangrove merupakan daerah peralihan (ekoton) antara ekosistem darat dengan ekosistem laut. Salinitas di perairan ekosistem ekoton ini diprediksi sangat bervariasi, dipengaruhi oleh peristiwa pasang-surut dan masukan air hujan (storm water) dari daratan, kondisi ini membuat hanya spesies-spesies dengan daya toleransi cukup tinggi saja yang dapat hidup daerah ini. Jenis fitoplankton yang mendominasi adalah Nannochloropsis oculata. Nannochloropsis oculata pada perairan berperan sebagai pakan alami larva-larva ikan, hal ini karena ukurannya yang sangat kecil sehingga sesuai dengan bukaan mulut larva. Selain Nannochloropsis oculata, jenis fitoplankton lain yang cukup mendominasi adalah Ceratium fusca. Jenis-jenis Ceratium tidak disukai sebagai pakan alami ikan karena tubuhnya diselimuti oleh cangkang keras dan tajam; apabila masuk ke rongga mulut, Ceratium dapat melukai insang ikan. Adanya jenis-jenis yang mendominasi (Nannochloropsis oculata dan Ceratium fusca) membuat indeks keseragaman menjadi rendah $(<0,3)$. Jumlah jenis fitoplankton yang banyak dijumpai adalah dari Kelas Bacillariophyceae 
(Diatom) dan Dinophyceae. Menurut Nybakken (1992), fitoplankton berukuran besar yang tertangkap oleh jaring plankton terdiri dari dua kelompok besar, yaitu Diatom (Bacillariophyceae) dan Dinoflagellata. Diatom adalah komponen utama dalam komunitas plankton, yang mana kehidupan laut tergantung padanya (Microsoft Encarta, 2008).

Tabel 1. Struktur Komunitas Fitoplankton

\begin{tabular}{|c|c|c|}
\hline No & Nama Spesies & Kelimpahan (ind/l) \\
\hline & Bacillariophyceae (Diatom) & \\
\hline 1 & Thalassiosira sp. & 100 \\
\hline 2 & Rhizosolenia spp. & 100 \\
\hline 3 & Fragilaria sp. & 113 \\
\hline 4 & Rhabdonema arcuatum & 113 \\
\hline 5 & Nitzschia closterium & 138 \\
\hline 6 & Triceratium antediluvianum & 163 \\
\hline 7 & Bidulphia granulata & 100 \\
\hline \multirow[t]{2}{*}{8} & Bidulphia levis & 50 \\
\hline & Dinophyceae & \\
\hline 9 & Ceratium fusca & 650 \\
\hline \multirow[t]{2}{*}{10} & Ceratium longinu & 75 \\
\hline & Chrysophyceae & \\
\hline \multirow[t]{5}{*}{11} & Nannochloropsis oculata & $>12500$ \\
\hline & Total & $>14100$ \\
\hline & Indeks Keanekaragaman Shannon-Wiener (H') & 0,58 \\
\hline & Indeks Keseragaman Evennes (E) & 0,24 \\
\hline & Indeks Dominansi Simpson (D) & 0,79 \\
\hline
\end{tabular}

Nilai Indeks Keanekaragaman Jenis fitoplankton adalah 0,58 yang artinya tergolong rendah (karena nilainya $<1$ ), kondisi ini menunjukkan kualitas lingkungan yang kurang baik. Hal tersebut juga didukung dengan rendahnya nilai Indeks Keseragaman Jenis $(0,24)$ dan tingginya nilai Indeks Dominansi Jenis $(0,79)$. Nilai Indeks Keseragaman Jenis yang rendah menunjukkan bahwa komunitas fitoplankton berada dalam kondisi yang tidak stabil, dimana jumlah spesies antar individu tidak sama dan ada spesies yang mendominansi (Basmi, 2000; Odum 1998).

Untuk zooplankton, hanya ada dua jenis yang dijumpai, yaitu nauplius Sergia lucens (larva sejenis kepiting) dan nauplius Acartia clausii (larva sejenis udang kecil), keduanya dijumpai dalam kelimpahan yang sama (yaitu 100 individu/liter). Kondisi tersebut membuat indeks keseragaman maksimum (1) dan indeks dominansi sedang (0,5). Nilai Indeks Keanekaragaman Jenis zooplankton adalah 0,69 yang artinya tergolong rendah. Rendahnya 
nilai indeks keanekaragaman zooplankton ini dipengaruhi oleh rendahnya keanekaragaman fitoplankton, hal ini karena fitoplankton dan zooplankton terkait dalam satu rantai makanan. Zooplankton merupakan herbivora primer di laut yang merupakan konsumen langsung dari fitoplankton (Nybakken, 1992).

Tabel 2. Struktur Komunitas Zooplankton

\begin{tabular}{clc}
\hline No & \multicolumn{1}{c}{ Nama Spesies } & Kelimpahan (ind/l) \\
\hline \multirow{2}{*}{1} & Malacostraca & 100 \\
& $\begin{array}{l}\text { Sergia lucens (nauplius) } \\
\text { Crustacea }\end{array}$ & \\
& Acartia clausii (nauplius) & 100 \\
\hline & Total & 200 \\
\hline & Indeks Keanekaragaman Shannon-Wiener (H') & 0,69 \\
& Indeks Keseragaman Evennes (E) & 1,00 \\
& Indeks Dominansi Simpson (D) & 0,50 \\
\hline
\end{tabular}

Tabel 3. Hasil Analisis Kualitas Air Muara Sungai

\begin{tabular}{lccc}
\hline \multicolumn{1}{c}{ Parameter } & Unit & Hasil analisis & Metode analisis \\
\hline Kekeruhan/Turbiditas & NTU & 3 & APHA-2130-B \\
Total Suspended Solid (TSS) & $\mathrm{mg} / \mathrm{L}$ & 46,00 & APHA-2540-D \\
$\mathrm{pH}$ & - & 7,05 & APHA-4500-H \\
Salinitas & $\% / \mathrm{oo}$ & 31,00 & APHA-2520-B \\
Minyak dan Lemak & $\mathrm{mg} / \mathrm{L}$ & $<0,20$ & APHA-5520-E \\
\hline
\end{tabular}

Keterangan: Data sekunder. Analisis kualitas air dilakukan oleh SUCOFINDO - Batam; Metode Analisis berdasarkan Standard Methods APHA-AWWA $19^{\text {th }}$ edition (1995)

Data pada Tabel 3 menunjukkan bahwa salinitas perairan saat pengambilan sampel plankton tergolong tinggi, yaitu $31 \%$, hal ini menunjukkan bahwa muara sungai pada saat itu sangat dipengaruhi oleh masukan air pasang dari laut. Mengacu pada Baku Mutu Air Laut untuk Biota Laut (Kementerian Lingkungan Hidup, 2004), nilai salinitas pada ekosistem mangrove sangat bervariasi dengan nilai bisa mencapai $34 \%$, dengan demikian salinitas di Muara Sungai Enam ini tergolong normal. Berdasarkan baku mutu tersebut, kisaran pH pada air laut untuk biota laut adalah antara 7 - 8,5 (Kementerian Lingkungan Hidup, 2004); dengan demikian nilai pH di Muara Sungai Enam juga tergolong normal.

Ambang batas kekeruhan pada air laut untuk biota laut adalah 5 NTU (Kementerian Lingkungan Hidup, 2004); hasil pengukuran di Muara Sungai Enam menunjukkan angka 3 NTU, dengan demikian nilainya sesuai dengan baku mutu. Kekeruhan menggambarkan sifat optik air yang ditentukan berdasarkan banyaknya cahaya yang diserap dan dipancarkan oleh 
bahan-bahan yang terdapat dalam air. Kekeruhan dapat disebabkan oleh mikroorganisme atau detritus organik; silika atau mineral lainnya termasuk Zn, Fe, dan Mn; serta debu, pasir, dan tanah liat baik yang berasal dari proses alami maupun yang berasal dari kegiatan domestik dan industri (Bhattacharya, 1992). Kekeruhan terutama disebabkan oleh erosi tanah di DAS maupun di saluran/sungai. Air sungai biasanya menjadi lebih keruh pada saat terjadi hujan lebat dibandingkan pada kondisi normal (Suripin, 2002). Pada Muara Sungai Enam, kekeruhan bisa diakibatkan oleh kandungan mikroorganisme (termasuk plankton) dan erosi tanah dari lahan yang dibuka untuk pertambangan bijih bauksit.

Ambang batas TSS pada air laut untuk biota laut di ekosistem mangrove adalah 80 mg/l (Kementerian Lingkungan Hidup, 2004); hasil pengukuran di Muara Sungai Enam menunjukkan konsentrasi $46 \mathrm{mg} / \mathrm{l}$, dengan demikian nilainya sesuai dengan baku mutu. Total Suspended Solid (TSS) adalah bahan-bahan tersuspensi yang tertahan pada kertas saring millipore berdiameter pori $0,45 \mu \mathrm{m}$ (Mays, 1996). TSS dalam air umumnya terdiri dari fitoplankton, zooplankton, kotoran manusia, kotoran hewan, lumpur, sisa tanaman dan hewan, serta limbah industri. Erosi tanah akibat hujan lebat dapat mengakibatkan naiknya nilai TSS secara mendadak (Sastrawijaya, 2000).

\section{KESIMPULAN}

Secara keseluruhan dapat disimpulkan bahwa keanekaragaman jenis fitoplankton di Muara Sungai Enam tergolong rendah. Hal ini karena muara sungai merupakan daerah peralihan (ekoton) antara ekosistem darat dengan ekosistem laut. Salinitas di perairan ekosistem ekoton ini diprediksi sangat bervariasi, kondisi ini membuat hanya spesies-spesies dengan daya toleransi cukup tinggi saja yang dapat hidup daerah ini. Walaupun demikian produktivitasnya cukup baik karena fitoplankton yang mendominasi adalah Nannochloropsis oculata. Nannochloropsis oculata pada perairan berperan sebagai pakan alami larva-larva ikan. Sejalan dengan fitoplankton, zooplankton yang merupakan herbivora primer juga memiliki keanekaragaman jenis yang rendah.

\section{REFERENSI}

Basmi, J. 2000. Planktonologi: Plankton sebagai Bioindikator Kualitas Perairan. Fakultas Perikanan dan Ilmu Kelautan. Institut Pertanian Bogor. Bogor. 
Bhattacharya, S. K. 1992. Urban Domestic Water Supply in Developing Countries. CBS Publishers \& Distributors. New Delhi.

Fachrul, M. F. 2012. Metode Sampling Bioekologi. Bumi Aksara. Jakarta.

Kementerian Lingkungan Hidup - RI, 2004. Keputusan Menteri Lingkungan Hidup Nomor 51 Tahun 2004 tentang Baku Mutu Air Laut. Kementerian Lingkungan Hidup - RI. Jakarta

Mays, L. W. 1996. Water Resources Handbook. McGraw-Hill. New York.

Microsoft Encarta. 2008. Diatom. Microsoft Corporation. Redmond, WA - USA.

Nontji, A. 2008. Plankton Laut. LIPI Press. Jakarta.

Nybakken, J. W. 1992. Biologi Laut: Suatu Pendekatan Ekologis. PT. Gramedia Pustaka Utama. Jakarta.

Odum, E. P. 1998. Dasar-Dasar Ekologi. Gadjah Mada University Press. Jogjakarta.

Sastrawijaya, A. Tresna. 2000. Pencemaran Lingkungan. Penerbit Rineka Cipta. Jakarta.

Suripin. 2002. Pelestarian Sumberdaya Tanah dan Air. Penerbit ANDI. Yogyakarta.

Yamaji, I. 1979. Illustrations of the Marine Plankton of Japan. Hoikusha Publishing Co., Ltd. 